\title{
Model Literasi Media Berbasis Kearifan Lokal pada Suku Dayak Tunjung dan Dayak Benuaq di Kutai Barat ${ }^{1}$
}

\author{
Inda Fitryarini ${ }^{1}$ \\ Rina Juwita ${ }^{3}$ \\ Purwaningsih ${ }^{4}$
}

\begin{abstract}
This study begins from a simple question on how Dayak Benuaq and Dayak Tunjung/Tonyoii people (individually and collectively) are able to maintain their local wisdom and local culture in the midst of the ambush of mass media exposure and then acknowledged as the Dayak tribes who are still 'Beradat (Wellmannered)". Their local wisdom which is still maintained were able to counteract the negative effects of mass media exposure so it can be used as a model of literacy media, either through media literacy education or media literacy movement. This study used a qualitative explanatory method and used a communication ethnographic approach in field. Primary data was collected through interviewsed and observations of some Dayak Benuaq and Dayak Tunjung people, including some community leaders and local government officials that found with the snowball sampling technique. The results showed that, first, public awareness through the local wisdom lense in media literacy has not been able yet to maximize their own potential due to society passivity as media users, as well as a lack of support from the government to create a media savvy society. Second, the model used within both tribes is known as Protectionist Model based on their local wisdom which includes four kinds of elements, which are; the ability to access, to analyse, to evaluate, and to create content.
\end{abstract}

\section{Keywords:}

media literacy; local wisdom; Dayak Tunjung; Dayak Benuaq

\begin{abstract}
Abstrak
Penelitian ini bertitik tolak dari permasalahan bagaimana individu dan kolektif suku Dayak Benuaq dan Dayak Tunjung/Tonyooi masih mampu mempertahankan kearifan lokal dan budaya lokal ditengah gempuran terpaan media massa sehingga dikenal sebagai suku Dayak yang masih "Beradat". Kearifan lokal yang masih terjaga mampu menangkal dampak negatif terpaan media massa sehingga dapat dijadikan sebuah model literasi media, baik melalui pendidikan literasi media maupun gerakan literasi media. Penelitian ini menggunakan metode eksploratif kualitatif dengan pendekatan etnografi komunikasi. Data primer dikumpulkan melalui wawancara dan observasi dari beberapa masyarakat suku Dayak Benuaq dan Dayak Tunjung, tokoh masyarakat, dan aparat pemerintah kabupaten dengan teknik snowball sampling. Hasil penelitian menunjukkan

\footnotetext{
1 Versi awal tulisan ini telah disampaikan pada Konferensi Nasional Komunikasi 2013 “Pengguna Media dan Lokalitas", 13-14 November 2013 di Departemen Ilmu Komunikasi Universitas Indonesia.

1 Dosen Tetap Program Studi Ilmu Komunikasi FISIP Universitas Mulawarman.

Email: inda.unmul@gmail.com, ghaida_lutfiyah@yahoo.com

3 Dosen Prodi Ilmu Komunikasi Universitas Mulawarman

Email: ghaida_lutfiyah@yahoo.com

4 Dosen Prodi Ilmu Sosiologi Universitas Mulawarman

Email: purwaningsih02@gmail.com
} 
bahwa pertama, kesadaran masyarakat melalui kearifan lokal dalam literasi media belum mampu memaksimalkan potensinya sendiri disebabkan masyarakat masih menjadi pengguna media yang pasif serta kurangnya dukungan dari pemerintah dalam membentuk masyarakat cerdas bermedia. Kedua, model literasi media yang digunakan kedua suku adalah Protectionist Model berbasis kearifan local meliputi 4 elemen yaitu kemampuan mengakses, menganalisis, mengevaluasi dan memproduksi pesan.

\section{Kata kunci:}

literasi media; kearifan lokal; Dayak Tunjung, Dayak Benuaq.

\section{Pendahuluan}

Media massa memainkan peranan penting pada saat ini sehingga setiap individu tidak mungkin dapat mengasingkan diri dari pengaruhnya. Kenyataannya saat ini khalayak terus diterpa oleh ribuan pesan melalui media baik dalam bentuk-bentuk yang standar seperti poster, radio, televisi hingga games. Hal ini menunjukkan bahwa dalam segi isi media telah mampu "menguasai" individu. Ini akan berdampak pada perubahan psikologis hingga sosial tanpa disadari. Bukan hanya sekedar menggunakan media, kini khalayak sudah sampai pada taraf candu. Efek media massa akibat perkembangan teknologi komunikasi dan informasi bisa positif maupun negatif.

Salah satu dampak negatif yang terjadi di masyarakat adalah kasus kematian seorang anak yang disebabkan film animasi "Naruto". Film kartun yang ditayangkan di Global TV pada tahun 2008 yang lalu diduga telah menyebabkan kematian Revino Siahaya. Selain televisi, internet juga memiliki efek yang cukup mengkhawatirkan. Kasus penculikan melalui media facebook, dan juga modus yang jarang terjadi, yaitu facebook menjadi media yang efektif untuk mencuri motor. Kedua kasus tersebut menunjukkan bahwa beberapa khalayak media khususnya anak dan remaja masih belum memiliki filter dalam mencegah efek tayangan media massa.

Kondisi saat ini, masyarakat Indonesia belum memiliki tingkat literasi media yang cukup tinggi. Praktek model literasi media yang ditemui sekarang ini berbasis pada model-model yang berasal dari Amerika Serikat dan Eropa dimana kondisi social berbeda. Hal ini menimbulkan kesan bahwa masyarakat Indonesia tidak mempunyai model untuk membuat masyarakat cerdas bermedia. Padahal jika dikaji secara mendalam kearifan local yang tersebar diberbagai suku di Indonesia banyak mengajarkan mengenai kearifan yang dapat diadopsi kedalam model literasi media.

Salah satu daerah yang memiliki kearifan local yang masih terjaga hingga kini adalah Kutai Barat. Kutai Barat sebagai kabupaten baru yang berdiri tahun 1999, merupakan sebuah Kabupaten hasil pemekaran dari Kabupaten Kutai Kartanegara yang memiliki karakteristik dan kekhususan sosial budaya yang sangat khas. Sebagai sebuah Kabupaten baru, maka berbagai persoalan muncul seiring dengan lajunya dinamika penduduk Kutai Barat, baik problematika yang dirasakan oleh penduduk pendatang yang tinggal menetap dan pendatang musiman, maupun berbagai masalah sosial penduduk asli (penduduk lokal).

Kekhawatiran tersebut muncul akibat terpaan media massa yang semakin masif di wilayah Kutai Barat. Berdasarkan informasi 12 KPID perbatasan, ditemukan fakta bahwa TVRI dan RRI belum bersiaran banyak di wilayah Kutai Barat, Nunukan dan Malinau (Sumber: Buku Profil dan Dinamika Penyiaran di daerah Perbatasan NKRI, 2012). Ketiga daerah tersebut merupakan daerah yang langsung berbatasan dengan Malaysia. Di Kalimantan 
Timur, khususnya bagian utara, sebagian besar perangkat radio dan televisi diisi oleh siaran-siaran yang dipancarkan dari negara tetangga Malaysia. Siaran-siaran itu dapat dengan mudah diterima meski hanya dengan menggunakan perangkat penerima siaran yang lazim dengan menggunakan antena biasa (Sumber: Kaltim Post, 17 Mei 2006). Sementara itu, masyarakat di Kutai Barat banyak yang menikmati tayangan televisi melalui TV Kabel Berlangganan.

Khaerul (KPID Kaltim) mengungkapkan bahwa masyarakat pada akhirnya menonton tayangan TV asing daripada tayangan TV nasional (Sumber: www.antaranews.com, 28 September 2011). Hal tersebut diperparah dengan kenyataan bahwa masyarakat di daerah Kalimantan Timur lebih banyak diterpa informasi dari Jakarta maupun kota lain di Jawa, sedangkan siaran lokal justru sangat minim. Kondisi lain yaitu bahwa di Kutai Barat belum ada televisi komunitas maupun Koran kampung. Sedangkan untuk media cetak lokal yaitu Kaltim Pos, Tribun Kaltim dan Koran Kaltim.

Berkaitan dengan literasi media maka muncul ide untuk menyaring serbuan informasi dari media massa melalui kearifan lokal. Secara teoritis, kearifan lokal merupakan manifestasi dari ajaran-ajaran budaya yang dihidupi oleh suatu masyarakat lokal. Budaya tersebut mampu digunakan sebagai filter untuk menyerap dan mengolah kebudayaan asing yang terpublikasikan ke masyarakat melalui media massa. Menurut penggiat literasi media dari Universitas Diponegoro, Sunarto, gerakan literasi media idealnya dapat memanfaatkan kearifan lokal yang ada di daerah masingmasing. Ini seperti halnya ritual "ngrowot" atau "mutih" yang biasa dilakukan kalangan suku Jawa. Esensi dari puasa "mutih" dan "ngrowot" adalah pembatasan dari jenis makanan yang masuk ke tubuh manusia sehingga hal ini dapat diadopsi sebagai salah satu nilai filosofis yang berlaku pula bagi konsumsi media.
Berdasarkan permasalahan diatas, diperlukan sebuah kajian awal tentang kearifan lokal Komunitas Dayak sebagai komunitas asli Kalimantan Timur khususnya suku Dayak Benuaq dan Dayak Tunjung dalam menghadapi terpaan media massa. Kearifan lokal yang dimiliki suku Dayak Benuaq dan Dayak Tunjung merupakan kekayaan luar biasa yang perlu dilestarikan dalam rangka menangkal budaya luar yang tidak sesuai dengan nilai-nilai bangsa dimana kedua suku Dayak tersebut dikenal masih sangat memegang teguh adat dan budaya lokal mereka (Sumber: Ristoja 2012). Permasalahan dalam penelitian ini adalah: (1) Apa saja kearifan lokal suku Dayak Tunjung dan Dayak Benuaq di Kabupaten Kutai Barat Kalimantan Timur? (2) Bagaimana model literasi media berbasis kearifan lokal pada suku Dayak Benuaq dan Dayak Tunjung di Kutai Barat Kalimantan Timur?

Berkaitan dengan permasalahan yang dikemukakan, tujuan penelitian ini adalah: (1) untuk menggali dan mendeskripsikan berbagai kearifan local suku Dayak Tunjung dan Dayak Benuaq di Kutai Barat; (2) mendeskripsikan dan memahami model literasi media berbasis kearifan lokal pada suku dayak Tunjung dan Dayak Benuaq di Kutai Barat. Manfaat penelitian ini yaitu mendorong terwujudnya pendidikan maupun gerakan literasi media berbasis kearifan lokal di wilayah Kutai Barat.

Penelitian ini menggunakan teori kegunaan dan gratifikasi (Uses and Gratification Theory) dari Elihu Katz dan, Jay G. Blumner dan Michael Gurevitch (Richard West and Lynn H Turner; 2007). Teori ini menyatakan bahwa orang secara aktif mencari media tertentu dan isi (content) tertentu untuk menghasilkan kepuasan (atau hasil) tertentu. Dalam pengembangan teori ini dikatakan orang aktif karena mereka mampu untuk mempelajari dan mengevaluasi berbagai jenis media untuk mencapai tujuan tertentu. 
Guna menguatkan dampak media massa, digunakan teori masyarakat massa (Mass Society Theory) yang diusung oleh Kornhouser (1959), Bromson (1961), Giner (1979), dan (Dennis Mc Quail 1991). Dalam teori ini dijelaskan bahwa, rata-rata orang merupakan korban media massa (Richad West and Lynn $\mathrm{H}$ Turner 2007). Guna mengulas terpaan media massa dan khalayak maka berpijak pada argumen khalayak tidak peduli Richard T. La Piere, dalam bukunya yang berjudul Theory of Social Control berpendapat bahwa lingkungan inti seperti rumah atau keluarga, gereja dan jaringan persahabatan, lebih mempengaruhi nilai-nilai, sikap dan perilaku individu ketimbang media. Orang-orang berpaling ke media untuk memperoleh apa yang mereka cari, bukannya menyediakan diri untuk dipengaruhi. Richard juga menyatakan bahwa seseorang tidak mudah mengubah keyakinannya karena hubungan media yang berjarak dan umumnya orang-orang akan lebih mempercayai kelompok sosial terdekatnya. Pesan media baru akan diterima jika itu sesuai dengan pesan lingkungan sosial (L. Rivers, 2008:40).

Sedangkan model yang digunakan untuk mengulas literasi media berbasis kearifan lokal, berpijak pada model yang dikembangkan oleh Rumah Sinema pada tahun 2012, yaitu bahwa ada 4 (empat) model yang dikembangkan dalam literasi media: pertama adalah Protectionist Model, model ini mengharuskan khalayak memilih tontonan yang baik dan menghindari tontonan yang buruk. Bentuk kegiatannya adalah Diet Media, pengaturan jadwal menonton, dan sejenisnya. Menurut Dyna Herlina S, M.Sc (peneliti Rumah Sinema), model ini cocok untuk khalayak yang punya kemampuan dan pendidikan terbatas. Kedua, adalah model Uses dan Gratification. Model ini membekali khalayak dengan kemampuan memilih dan memilah konten media. Bentuk kegiatannya adalah mempelajari kerja media. Dengan demikian khalayak mampu membuat keputusan sendiri dalam memilih media. Ketiga, adalah model Cultural Studies. Model ini mengajak khalayak untuk menganalisis dan mengkrisitisi media. Bentuk kegiatannya dapat berupa Kampanye Hari Tanpa TV, Advokasi UU Penyiaran, Boikot Media, dan lain-lain. Keempat, adalah model Active Audience. Model ini melatih khalayak agar mampu menginterpretasi konten media berdasarkan latar belakang masing-masing. Baik secara sosial maupun kultural. Bentuk kegiatannya sampai kepada memproduksi media sesuai dengan aspirasinya. (Sumber: KPI 2012)

\section{Metode Penelitian}

Jenis penelitian ini adalah penelitian eksploratif (exploratory research) yang mengkaji secara mendalam kearifan lokal dalam menghadapi terpaan media massa di Kabupaten Kutai Barat. Menurut Ida Bagoes Oka (2004) penelitian eksploratif yang dimaksud adalah penelitian yang bersifat terbuka dengan penekanan utamanya adalah menemukan gagasan maupun pandangan. Penelitian ini berusaha untuk mengungkapkan model literasi media berbasis kearifan lokal berkaitan pencegahan dampak negatif terpaan media massa hingga sampai pada tahap produksi pesan media.

Sedangkan pendekatan yang digunakan dalam penelitian ini adalah pendekatan etnografi. Etnografi adalah uraian dan penafsiran suatu budaya atau sistem kelompok sosial. Menurut Pawito (2008:149) etnografi sangat lekat dengan kebudayaan. Kebudayaan bahkan merupakan hal yang pokok dalam studi etnografis.

Data yang dikumpulkan adalah data primer dan data sekunder. Data primer diperoleh dari wawancara semi terstruktur dengan pihak-pihak terkait terutama tokoh adat, tokoh masyarakat, komunitas masyarakat suku Dayak Tunjung dan Dayak Benuaq, dan Pemerintah Daerah. Teknik pengumpulan data sekunder yang dikumpulkan dalam penelitian ini yaitu dari berbagai literatur/ 
pustaka, statistik kependudukan lokasi penelitian, monografi lokasi penelitian serta dilakukan observasi partisipasi dan non-partisipasi. Metode wawancara dilakukan secara terbuka dengan memilih informan kunci (key informant). Key informant dalam penelitian ini berjumlah 6 orang.

Teknik sampling yang digunakan yaitu snowball sampling dengan jumlah informan sebanyak 3 orang. Informan kunci terdiri dari: 2 orang tokoh masyarakat dari suku Dayak Tunjung dan Dayak Benuaq, pihak Pemerintah Daerah (Bupati Kutai Barat, 1 orang Humas Pemerintah Kabupaten Kutai Barat, 2 orang Dinas Kebudayaan dan Pariwisata ). Sedangkan informannya meliputi: 1 orang dukun upacara adat Belian, dan 2 orang masyarakat suku Dayak Tunjung dan Dayak Benuaq pengguna media massa. Validitas data dalam penelitian ini menggunakan trianggulasi yang terdiri dari trianggulasi metode, sumber, teori dan peneliti.

Penentuan lokasi penelitian menggunakan teknik purposive sampling dengan kriteria desa/ kampung dihuni oleh masyarakat suku Dayak Benuaq dan Dayak Tunjung di wilayah Kutai Barat yang diterpa media massa. Terdapat 20 kampung yang dijadikan sebagai wilayah observasi dalam penelitian ini. Pendekatan analisis dengan menggunakan beberapa metode analisis yaitu analisis data interaktif yang terdiri dari pengumpulan data, analisis data, verifikasi data dan kesimpulan dari Milles Huberman serta perumusan hasil.

\section{Hasil Penelitian dan Pembahasan}

\section{Identifkasi Kearifan Lokal Suku Dayak Tunjung dan Dayak Benuaq}

Seperti telah disinggung dalam bab sebelumnya bahwa mendefinisikan literasi media tidak hanya dari aspek teknologinya tetapi juga harus menyentuh aspek budayanya yang menjadi konteks dimana literasi media tersebut diciptakan dan diwujudkan guna mencegah serta menanggulangi dampaknya.
Dimana keraifan lokal (local wisdom) merupakan gagasan masyarakat setempat yang bersifat bijaksana, penuh dengan kearifan, bernilai baik yang tertanam nilai-nilai dan diikuti masyarakatnya (Darmastuti, 2012:24).

Di lain pihak, rendahnya pengetahuan dan keterbatasan teknologi pada masyarakat tradisional berkorelasi dengan perilaku, kebiasaan, norma dan kelembagaan yang sangat memperhatikan lingkungan (dalam hal ini lingkungan sosial). Ketidakmampuan masyarakat tradisional pada sisi lain merupakan kearifan tersendiri terhadap lingkungan sosial yang sudah semakin terganggu akhir-akhir ini. Gangguan tersebut salah satunya berasal dari pesan-pesan media massa yang semakin masif.

Masyarakat suku Dayak Tunjung dan Dayak Benuaq berada pada kondisi peralihan/ transisi, dari tradisional menuju modern. Hal tersebut merupakan akibat dari pemekaran Kabupaten Kutai Barat sehingga Pemerintah Daerah selalu menekankan pada perubahan berbagai bidang. Salah satu bidang yang ditekankan oleh Pemerintah Kutai Barat adalah tersedianya akses teknologi informasi dan komunikasi serta media massa (Sumber: Profil Kutai Barat, 2013).

Hasil identifikasi terhadap kearifan lokal suku Dayak Tunjung dan Dayak Benuaq di Kutai Barat adalah seperti pada Tabel 1.

Tabel 1 merupakan nilai-nilai lokal yang dianut oleh masyarakt suku Dayak Benuaq dan Dayak Tunjung. Nilai-nilai tersebut dapat dikelompokkan menjadi beberapa kelompok yaitu antara lain:

1. Nilai ketaatan kepada hukum adat

2. Nilai kekeluargaan

3. Nilai harmoni dengan alam

4. Nilai kepemimpinan

\section{Model Literasi Media Berbasis Kearifan Lokal}

Literasi media adalah kemampuan untuk mengakses, menganalisis, mengevaluasi dan 
Tabel 1.

\section{Produk}

Kebudayaan

Pengetahuan 1. Bengkaar mentutn (Benuaq) yaitu hutan perawan yang masih asli.

Lokal

2. Batakng yaitu ladang yang dibuat setelah memotong/menebas serta menebang kayu. Usia ladang antara 15-20 tahun adan hanya boleh mengulang pada lahan yang sama sebanyak 2 (dua) kali.

3. Pembakaran ladang sebagai fungsi penyuburan.

Nilai Lokal 1. Dilarang berjalan tanpa tujuan jelas di depan pintu masuk ke bilik-bilik dalam rumah panjang.

2. Truaak Nedoq yaitu dilarang mengintip/menengok ke dalam ruangan tempat tinggal orang lain.

3. Dilarang duduk sambil berjongkok dan arah pandangan mata ditujukan kepada orang-orang sedang mandi atau larangan "menonton" orang mandi.

4. Perempuan dilarang sendirian di kebun.

5. Belaboh yaitu mengancam orang dengan gerakan seperti ingin memukul, menombak atau mencabut parang seolah-olah ingin melukai/membunuh orang lain.

6. Dilarang memikul senjata/sumpit dengan posisi sejajar dengan bahu.

7. Puncuq nenaatn yaitu seseorang dilarang duduk ditengah jalan.

8. Harus selalu berlaku sopan.

9. Harus selalu menjaga perasaan orang lain agar tidak tersinggung.

10. Sempekat yakni kesepakatan atau musyawarah mufakat.

11. Gotong royong/Tonau (Tonyooi) dan Pelo (Benuaq).

12. Anye (Tonyooi), anyeeh (Benuaq) yaitu memberikan makanan, benda, uang atau jasa karena orang lain telah membantu.

13. Takut kawo mpeeq sake, takut negkaah mpeeq nyelekng yaitu jangan sampai dengan selalu meminta-minta belas kasihan seseorang, kita lupa untuk bekerja keras.

14. Pentaak (Tonyooi) dan manyaak (Benuaq) yaitu kewajiban memberi makan dan minum bagi para tamu.

15. Nimpaa (Tonyooi) dan lemaaq (Benuaq) yaitu perbuatan mengalah, tidak egois, tidak serakah (kebuhooq) dan tidak mementingkan diri sendiri agar terhormat di masyarakat.

16. Santaap (Tonyooi) dan sintap (Benuaq) yaitu memakan sedikit bagian dari hidangan makanan yang disuguhkan orang lain.

17. Mupu yaitu larangan mengambil buah-buahan sebelum masak.

18. Nganyaah yaitu larangan mengambil ikan dengan tuba, hanya boleh menggunakan tangan atau jaring.

19. Larangan membuang air kecil dan air besar di sungai (dahulu).

20. Kebersamaan, gotong royong =Tonau (Tunjung) dan Pelo (Benuaq), dan kepemimpinan.

21. Tidak boleh mencela orang lain.

22. Bersikap hormat terhadap semua makhluk.

23. Jangan sombong walaupun punya kedudukan tinggi, tetaplah lembut dan mudah ditemui.

24. Bersikap dan berperilaku jujur. 
sambungan dari halaman 6

\begin{tabular}{ll}
\hline Keterampilan & 1. Berburu \\
Lokal & 2. Meramu obat tradisional \\
& $\begin{array}{l}\text { 3. Bercocok tanam } \\
\text { 4. Tidak membunuh semua ikan di sungai dengan cara mengukur kekentalan } \\
\text { tuba. }\end{array}$ \\
& $\begin{array}{l}\text { 5. Membuat rumah panjang: Luuq (Tunjung), Louu (Benuaq) } \\
\text { 6. Membuat batik Doyo }\end{array}$ \\
& $\begin{array}{l}\text { 7. Membuat sumpit untuk berburu } \\
\text { 8. Permainan behempas, begasing, besumpit, belogo dan sabung kemiri. }\end{array}$ \\
& $\begin{array}{l}\text { 9. Rijok (Pantun) yang berisi petuah-petuah. } \\
\text { Sumber Daya }\end{array}$ \\
Lokal & Memitarian/kolektif \\
Mekanisme & Melalui dewan adat berpedoman pada aturan-aturan, denda sanksi adat sesuai \\
Pengambilan & perbuatan yang dilanggarnya. \\
Keputusan &
\end{tabular}

Sumber: Data primer dan sekunder, 2013

mengirimkan pesan dalam format cetak dan non cetak (televisi, video, film, iklan dan internet)(Potter, W.J;2005). Dalam UndangUndang Nomor 32 tahun 2002 tentang Penyiaran dikatakan bahwa negara menguasai spektrum frekuensi radio yang digunakan untuk penyelenggaraan penyiaran guna sebesar-besarnya kemakmuran rakyat. Jadi apapun informasi yang disampaikan media penyiaran harus dapat bermanfaat bagi publik, yakni kebutuhan akan siaran yang sehat. Berikut pembahasan literasi media berbasis kearifan lokal pada suku Dayak Tunjung dan Dayak Benuaq mengacu pada model Livingstone:

\section{Access}

Akses ditentukan oleh suatu proses sosial yang dinamis, bukan sebuah tindakan tunggal. Setelah akses awal dilakukan, pengembangan pemahaman (literasi) membawa pengguna untuk berkembang secara signifikan dan kontinu dalam berbagai kondisi akses (update, upgrade, pengembangan hardware dan aplikasi software). Persoalannnya adalah kesenjangan dalam materi sosial demografis, sumberdaya sosial dan simbolik, kesenjangan dalam mengakses pengetahuan, komunikasi dan partisipasi online akan terus berlangsung.

Mengakses yang digunakan dalam penelitian ini adalah kemampuan khalayak dalam mencari, mendapatkan, dan mengumpulkan informasi. Akses media bukan lagi masalah, apalagi untuk khalayak yang tinggal di Ibu Kota. Akses terhadap media dapat ditemukan kapan saja dan dimana saja. Ditinjau dari kemampuan mengakses media massa, masyarakat suku Dayak Benuaq dan suku Dayak Tunjung sudah cukup baik. Mereka sudah menjadi bagian khalayak media karena beberapa media cetak, elektronik bahkan layanan internet kecamatan sudah tersedia dan terjangkau. Tetapi untuk masyarakat suku Dayak Tunjung dan Dayak Benuaq khususnya yang masih tinggal di kampung Geleo Asa belum ada kemampuan mengakses media cetak maupun media digital. Hal tersebut disebabkan kondisi infrastruktur belum baik dan hanya tersedia 2 (dua) operator selular yaitu Indosat dan Telkomsel dengan ketersediaan jaringan yang minim.

Hasil observasi peneliti dibeberapa kecamatan di Kutai Barat, masyarakat kedua suku tersebut tidak ada yang melakukan 
aktivitas membaca media cetak terutama masyarakat yang tinggal di kampung-kampung seperti kampung Geleo Asa (sebuah kampung di kecamatan Barong Tongkok, Kutai Barat), Jelemuq, Sekolaq Darat dan Ongko Asa. Hal ini disebabkan tingkat pendidikan masyarakat khususnya generasi tua masih rendah. Ratarata masyarakat memiliki tingkat pendidikan SD dan SMP. Kampung-kampung tersebut didiami oleh suku Dayak Tunjung.

Walaupun tingkat pendidikan rendah tetapi kondisi rumah masyarakat Dayak Tunjung di kampung tersebut bisa dikatakan bagus dan besar, dengan halaman yang cukup luas, rata-rata rumah mereka terbuat dari beton permanen dan sebagian terbuat dari kayu ulin serta jarak antara rumah satu dengan yang lainnya saling berdekatan dan berhadapan. Hal tersebut menggambarkan bahwa jalinan kerjasama dan kekeluargaan masih melekat pada masyarakat suku Dayak Tunjung. Hampir setiap rumah di kampung ini memiliki mobil minimal 1 serta parabola Matrix yang berarti bahwa tiap rumah diterpa media televisi.

Terpaan media massa masih cukup rendah karena frekuensi mengakses masih terbilang sedikit. Hasil wawancara dengan 6 (enam) informan menyatakan bahwa mereka menggunakan/mengakses media massa hanya sekedar mencari hiburan dan informasi melalui media televisi. Rata-rata mereka mengakses atau menggunakan media massa tidak lebih dari 10 jam per minggu.

Sebagai masyarakat yang memegang teguh tradisi, suku Dayak Tunjung dan Dayak Benuaq memiliki cara mencegah efek negatif terpaan media yang disesuaikan dengan nilai budaya yang dianutnya. Cara tersebut diadopsi dari kearifan lokal yaitu santaap (Tonyooi) dan sintap (Benuaq) yaitu memakan sedikit bagian dari hidangan makanan yang disuguhkan orang lain. Hal tersebut dimaknai bahwa berbagai tayangan yang disuguhkan media massa sebagai tamu (teknologi komunikasi) yang datang di wilayah suku Dayak Tunjung dan Benuaq hanya dikonsumsi sebagian yang sesuai dengan selera (nilai) kedua suku Dayak tersebut. Sehingga, walaupun akses cukup baik tetapi mereka melindungi diri dari gempuran tayangan media massa. Tindakan ini dilakukan sebagai penghormatan terhadap orang lain, dalam hal ini media massa, sesuai karakter masyarakat suku Dayak yang bersifat terbuka. Secara formal, mereka memasukkan anakanaknya ke lembaga pendidikan pemerintah maupun swasta. Akan tetapi ketika sudah didalam rumah para orang tua memberikan penanaman nilai melalui keteladanan orang tua khususnya yang berkaitan dengan tata karma dan sopan santun.

\section{Analysis}

Analisis merupakan kemampuan yang dapat membantu seseorang dalam menjelaskan bentuk pesan, struktur, segmen, dampak pesan, dan lain sebagainya. Analisis berkaitan dengan kemampuan untuk mencari, mengubah, dan memilih informasi disesuaikan dengan kebutuhan individu. Teori kegunaan dan gratifikasi (Uses and Gratification Theory) menyatakan bahwa orang secara aktif mencari media tertentu dan isi (content) tertentu untuk menghasilkan kepuasan (atau hasil) tertentu. Dalam pengembangan teori ini dikatakan orang aktif karena mereka mampu untuk mempelajari dan mengevaluasi berbagai jenis media untuk mencapai tujuan tertentu.

Dalam hal kemampuan menganalisis isi pesan media, para informan menyatakan bahwa mereka terutama anak-anak belum menyadari efek negatif tayangan media massa. Mereka belum mengetahui bahwa realitas di media massa dikonstruksikan sedemikian rupa berdasarkan ekonomi politik media massa tersebut. Masyarakat juga belum mengembangkan berbagai kemampuan untuk memanfaatkan berbagai kesempatan yang ditawarkan media online.

Hal tersebut terungkap dari hasil wawancara dengan Bapak Ismail Thomas, 
Bupati Kutai Barat. Beliau mengatakan bahwa media massa selama ini belum memberikan efek negatif pada masyarakat Kutai Barat. Keberadaan media massa di Kutai Barat justru mendukung pelestarian nilai-nilai dan budaya Kutai Barat khususnya media radio. Tentang keberadaan siaran Malaysia yang ada di perbatasan Kutai Barat, selama ini tidak menimbulkan permasalahan karena masyarakat Kutai Barat sangat menjunjung adat istiadat dan hukum adat. Bupati Kutai Barat mengatakan saat ini belum memerlukan lembaga khusus dalam mencegah dampak negatif terpaan media massa.

Kearifan yang dianut oleh suku Dayak Tunjung dan Dayak Benuaq berkaitan kemampuan analisis pesan media yaitu anjuran Nimpaa (Tonyooi) dan lemaaq (Benuaq) yaitu perbuatan mengalah, tidak egois, tidak serakah (kebuhooq) dan tidak mementingkan diri sendiri agar terhormat di masyarakat. Hal ini dimaknai bahwa tayangan yang bertolak dari anjuran tersebut tidak layak di konsumsi sehingga dampak tayangan tersebut tidak terjadi pada pengguna media. Dalam hal ini, menurut informan yang menggeluti bidang Seni dan Budaya Kutai Barat, walaupun masyarakat belum memiliki kemampuan menganalisis pesan media massa secara maksimal, kurang peka terhadap konstruksi tayangan media massa tetapi nilai-nilai budaya masyarakat Suku Dayak Benuaq dan Dayak Tunjung yang mengajarkan kerjasama, perdamaian dan kerja keras tetapi mereka mampu menentukan tayangan yang layak ditonton maupun tidak layak ditonton.

\section{Evaluation}

Evaluasi adalah kemampuan untuk menghubungkan antar pesan media yang diterima dengan pengalaman. Mengevaluasi informasi berdasarkan parameter, seperti kebenaran, kejujuran, dan kepentingan dari produsen pesan. Jadi, dengan mengevaluasi menyadarkan bahwa khalayak tetap memiliki hak prerogratif dalam memaknai pesan media untuk dirinya sendiri.

Dari enam informan yang diwawancarai, mereka belum mampu melakukan evaluasi berdasarkan parameter tersebut. Hal ini disebabkan media massa difungsikan sebagai media hiburan dan informasi yang didapatkan tidak dicek lagi dengan sumber lain. Berdasarkan perilaku para informan tersebut maka mereka termasuk kedalam khalayak pasif. Seperti dikutip dalam tulisan Ahmad Riza Faisal (67:2012) bahwa khalayak terbagi 2 (dua) yaitu khalayak pasif dan khalayak aktif. Jumlah khalayak pasif jauh lebih besar dibandingkan yang aktif. Mereka itu seperti diam saja ketika menerima informasi dari media massa bahkan tidak jarang tampak seperti tak berdaya. Kearifan lokal yang digunakan masyarakat suku dayak Tunjung dan Dayak Benuaq dalam mengevaluasi pesan media yaitu berpedoman pada nilai lokal. Nilai lokal tersebut antara lain yaitu mereka menganut kebersamaan, gotong royong=Tonau (Tunjung) dan Pelo (Benuaq), dan kepemimpinan. Halhal yang bersifat konflik akan dihindari oleh masyarakat kedua suku tersebut karena mereka meyakini bahwa kekerasan akan menyakiti sesama makhluk hidup.

\section{Content Creation}

Memproduksi pesan sebagai bagian dari kreativitas pesan adalah kemampuan seseorang menyusun pesan atau ide dengan kata-kata, suara, atau imej secara efektif sesuai dengan kaidah-kaidah ilmu komunikasi. Menciptakan media berkaitan dengan produksi dan distribusi isi media, juga berkaitan dengan kompetensi komunikatif.

Menurut Bupati Kutai Barat, di wilayah ini belum ada televisi komunitas dan media cetak komunitas walaupun dahulu sempat ada media cetak komunitas yang diolah oleh masyarakat Kutai Barat. Keberadaan radio lokal juga semakin berkurang karena terbentur dengan perijinan. Tetapi ada sebuah radio yang bernama Sendawar FM yang dimanfaatkan 
sebagai saluran melestarikan budaya lokal suku Dayak Tunjung dan Dayak Benuaq. Bahkan, menurut ibu Seki, radio tersebut dengan jam-jam siaran tertentu (biasanya sore hari) menghadirkan acara dengan bahasa daerah Dayak Tunjung atau kadangkala bahasa Dayak Benuaq sebagai pengantarnya.

Selain itu, radio tersebut juga sebagai saluran informasi kegiatan-kegiatan budaya, upacara adat di daerah tertentu di Kutai Barat untuk masyarakat yang tertarik menghadirinya dan mengikutinya. Masih menurut ibu Seki, radio Sendawar FM juga memiliki sajian acara dongeng atau cerita untuk anak-anak yang berisi tentang budaya nenek moyang suku Dayak Tunjung maupun Dayak Benuaq. Jika ditinjau dari fungsi media massa, radio Sendawar FM telah melaksanakan fungsinya sebagai media informasi, hiburan dan pewarisan nilai-nilai sosial.

Hasil observasi dan wawancara menunjukkan bahwa bila mengacu pada batasan literasi media Livingstone yang meliputi akses, analisis, evaluasi dan mencipta konten, misalnya, tentunya masyarakat suku Dayak Tunjung dan Dayak Benuaq tentu belum mencapai taraf tersebut bahkan bisa dikatakan belum mencapai harapan. Tetapi melalui kearifan lokalnya, efek negatif dari terpaan media massa dapat dicegah sehingga budaya yang berkembang pada masyarakat suku Dayak Tunjung dan Dayak Benuaq masih tercermin pada budaya lokal bukan budaya media. Masyarakat suku Dayak Tunjung dan Dayak Benuaq bisa dikatakan merupakan masyarakat atau khalayak tak peduli media. Hal tersebut disebabkan mereka terlalu mengacuhkan media. Meraka akan peduli media jika berita media massa berkaitan dengan kehidupan sosial mereka.

\section{Peran Pemerintah Daerah dalam Literasi Media}

Sebuah pemberdayaan sepatutnya melalui lembaga tertentu dan dukungan dari berbagai pihak. Dalam hal literasi media di Kutai Barat, belum ada sebuah lembaga yang menangani permasalahan literasi media. Bahkan pemerintah daerah menganggap belum diperlukan sebuah lembaga yang bergerak dalam bidang literasi media. Hal tersebut disebabkan belum terlihat adanya efek negatif berkaitan media massa yang ada di Kutai Barat. Bahkan, masih menurut Bupati Kutai Barat, hal yang perlu diwaspadai saat ini adalah masalah narkoba.

Berkaitan dengan literasi media, salah satu cara yang diterapkan pemerintah daerah untuk menyaring terpaan media massa dalam kehidupan masyarakatnya yaitu dengan cara memberikan acara dan kegiatan adat diwaktu senggang sehingga masyarakat tidak banyak memiliki waktu luang untuk menonton tayangan televisi swasta nasional maupun tayangan televisi luar negeri. Acara dan kegiatan adat tersebut seperti misalnya Festival Budaya yang diselenggarakan oleh Sempekat Dayak Tonyooi dan Dayak Benuaq, upacara adat Belian dan Kwangkey. Kedua upacara adat tersebut bahkan dijadikan hiburan oleh masyarakat setempat. Dalam upacara adat Belian, biasanya juga digelar pasar malam di sekitar lokasi upacara adat dan juga ada kegiatan judi. Judi ini sudah mendapatkan ijin dari pemerintah daerah dan lokasi perjudian ini agak jauh dari tempat keramaian upacara adat Belian. Hal ini menurut Dominus (40 tahun) dimaksudkan agar kegiatan judi tidak bisa dilihat anak-anak dan tidak dijadikan tontonan masyarakat.

Dari kondisi diatas maka terdapat tantangan yang dihadapi dalam hal penyelenggaraan literasi media di Kutai Barat. Beberapa tantangan tersebut adalah kurangnya dukungan dan kesadaran pemerintah daerah akan efek media massa. Dari pernyataan Bupati Kutai Barat, Bapak Ismail Thomas, bahwa pemerintah tidak menganggap isu literasi media sebagai sesuatu yang mendesak seperti hal lain yaitu narkoba, kemiskinan dan lain 
sebagainya. Keterlibatan pembuat kebijakan yang rendah juga akan menyebabkan literasi media tidak dapat diintegrasikan ke dalam sistem yang ada seperti sekolah dan lembaga non formal lainnya.

Akan tetapi, Bupati Kutai Barat sangat mendukung program peningkatan Sumber Daya Manusia. Hal ini terungkap dari wawancara yang menyatakan bahwa beliau mendukung semua program yang berkaitan dengan peningkatan SDM Kutai Barat termasuk penyadaran akan penerapan nilai-nilai adat dan agama dalam mengkonsumsi tayangan media massa.

Hasil observasi dan wawancara menunjukkan bahwa walaupun keberadaan lembaga yang menangani literasi media belum ada, pengembangan literasi media dapat dilakukan secara mandiri. Hal tersebut tampak di kedua suku Dayak ini yaitu masyarakatnya memiliki nilai kearifan lokal bahwa hewan, tumbuhan dan manusia berasal dari satu pohon kehidupan. Maka dari itu kekerasan sesama makhluk hidup sangat dihindari.

Dari nilai yang tertanam ini maka tayangan kekerasan tidak mendapat tempat pada khalayak di kedua suku Dayak ini. Mereka mencintai perdamaian dan hal tersebut sudah dibuktikan pada kasus konflik yang terjadi pada bulan November 2012 lalu, dimana konflik terjadi bukan berawal dari Suku Dayak tetapi suku Bugis yang memulai konflik tersebut. Bukti lain bahwa suku Dayak Benuaq dan Dayak Tunjung mencintai perdamaian adalah data-data Badan Pusat Statistik (BPS) tahun 2012, tidak ditemukan data yang berisi konflik, dan kekerasan di wilayah Kutai Barat. Perdamaian tersebut sangat wajar jika dirunut dari asal kedua suku mayoritas di Kutai Barat ini, khususnya karena mereka berasal dari satu raja yaitu Aji Tulur Jejangkat.

\section{Kesimpulan}

Penelitian ini menemukan beberapa kesimpulan yaitu: pertama, bahwa kesadaran masyarakat melalui kearifan lokal dalam literasi media belum mampumemaksimalkan potensinya sendiri disebabkan masyarakat masih menjadi pengguna media yang pasif. Sedangkan kearifan lokal suku Dayak Benuaq dan Dayak Tunjung dapat dikatakan masih terpelihara hingga kini khususnya kearifan berkaitan dengan lingkungan hidup dan lingkungan sosial. Walaupun diakui oleh beberapa informan, akibat perkembangan teknologi informasi, pengetahuan generasi muda terkait kearifan lokal semakin memudar. Kedua, tindakan literasi media memerlukan filter dalam bentuk kearifan lokal masyarakat. Model ini diimplementasikan atas dasar prinsip kerja sebagai berikut:

a. Produksi pesan dilakukan dengan cara menyajikan siaran-siaran budaya lokal suku Dayak Tunjung dan Dayak Benuaq melalui siaran radio lokal.

b. Protectionist model diterapkan dengan cara mengintensifkan kegiatan-kegiatan budaya lokal seperti festival budaya untuk kalangan remaja suku Dayak Tunjung dan Dayak Benuaq.

c. Pendampingan orang tua kepada anaknya dalam mengkonsumsi tayangan media massa dengan cara memberikan pemahaman tentang nilai-nilai lokal dalam suatu tayangan tertentu.

Ketiga, belum adanya dukungan maksimal dari pihak pemerintah daerah untuk memfasilitasi terbentuknya media televisi lokal maupun media komunitas lainnya sebagai salah satu bentuk kreativitas produksi pesan dalam elemen literasi media.

\section{Rekomendasi}

Untuk itu, rekomendasi dalam penelitian ini yaitu:

1. Bagi semua pihak baik pemerintah dan masyarakat diharapkan menjalin kerjasama dengan lembaga independen yang bergerak di bidang literasi media yaitu antara lain KPID Kaltim untuk menjalankan program pendidikan/gerakan literasi media. 
2. Selanjutnya, untuk mencapai 4 (empat) pilar tersebut maka diperlukan upaya implementasi pendidikan dan gerakan literasi media berbasis kearifan lokal melalui lembaga Sempekat Dayak Tonyooi dan Dayak Benuaq. Hal tersebut merupakan model pemberdayaan yang esensi dan urgensi untuk dikembangkan sebagai upaya mencegah dampak negatif terpaan media massa di masa mendatang khususnya di kalangan remaja dan meningkatkan kemampuan memproduksi pesan sendiri.

3. Penanganan permasalahan literasi media ini tidak mungkin ditangani sendiri oleh masyarakat tanpa adanya bantuan dari pemerintah maupun pihak-pihak yang berkompeten dalam hal ini. Bantuan tidak hanya berupa stimulan namun diharapkan lebih dalam bentuk pendampingan dan pemberdayaan bagi peningkatan kesadaran akan potensi sendiri serta peningkatan pengetahuan dan keterampilan dalam memanfaatkan potensi tersebut khususnya cerdas bermedia melalui kearifan lokal.

\section{Daftar Pustaka}

Aufderheide, P. (1993). Media Literacy: A Report of The National Leadership Conference on Media Literacy. Aspen: Aspen Institute.

Baran, Stanley J. (2011). Pengantar Komunikasi Massa: Literasi Media dan Budaya. Jakarta: Salemba Humanika.

Birowo, Mario Antonius. (2012). Perspektif Budaya Dalam Literasi Media. Artikel dalam Buku Literasi Media dan Kearifan Lokal. Yogyakarta: Buku Litera.

Budiastuti, Wiratmo. (2012). Literasi Media Berbasis Komunitas. Yogyakarta: Rumah Sinema.

Bungin, Burhan. (2008). Sosiologi Komunikasi. Jakarta: Kencana Prenada Media Group.

Darmastuti, Rini dkk. (2012). Literasi Media dan Kearifan Lokal: Konsep dan Aplikasi. Yogyakarta: Mata Padi Pressindo.
Devito, Joseph A. (2008). Essentials of Human Communication, Sixth Edition. Boston: Pearson Education, Inc.

Dyson P, Laurentius dan Emanuel. (2013). Kebijakan Tentang Budaya Lokal. UNESA: Fakultas Bahasa dan Seni.

Effendy, Onong Uchjana. (1984). Ilmu Komunikasi (Teori dan Praktek). Jakarta: PT. Remaja Karya.

Faizal, Ahmad Riza. (2012). Meretas Jalan Sosialisasi Literasi Media di Indonesia.

Griffin, EM.(2003). A First Look at Communication Theory. New York: McGraw Hill.

Kellner, Douglas. (2010). Budaya Media: Cultural Studies, Identitas dan Politik: Antara Modern dan Postmodern. Yogyakarta: Jalasutra.

Kellner, Douglas. (1995). Media Culture: Cultural Studies, Identity and Politics Between The Modern and The Postmodern. London and New Yorks: Routledge.

Kementerian Kesehatan. (2012). Ristoja; Pedoman Pengumpulan Data dan Pengisian Dokumen. Balitbangkes Kementerian Kesehatan RI.

KPI. (2012). Buku Profil dan Dinamika Penyiaran di daerah Perbatasan NKRI. Jakarta.

Lembaga Bina Desa Sejahtera (LBDS).( 2002). Modul Pelatihan Perencanaan Pembangunan Desa dengan Metode ZOPP. Jakarta: LBDS.

Lickona, Thomas. (1991). Educating For Character: How Our Schools Can Teach Respect and Responsibility. New York: Bantam Books.

Livingstone, S. (2004). What is Media Literacy?. Intermedia. 32: 18-20.

Martens, H. (2010). Evaluating Media Literacy Education: Concepts, Theories and Future Directions. Journal of Media Literacy Education 2 (1).

Massing, A.W. (1981). The Journey to Paradise: Funerary Rites of The Benuaq Dayak of East Kalimantan. Borneo Research Bulletin. Vol. 13 No. 2, hlm. 85-104.

Pawito. (2008). Penelitian Komunikasi Kualitatif. Yogyakarta: LKIS. 
Potter, James. W. (2004). Theory of Media Literacy: a Cognitive Approach. California: Sage Publications.

Potter, James. (2008). Media Literacy (4 $4^{\text {th }}$ ed.). California: Sage Publications Inc.

Rahardjo, Turnomo. (2012). Literasi Media dan Kearifan Lokal. Yogyakarta: Buku Litera.

Rosenbaum, J.E., Beentjes, J.W, J., \& Koenig, R.P. (2008). Mapping Media Literacy: Key Concepts and Future Directions. Communication Year Books, 32, pp. 313-353.

Saifuddin, Achmad Fedyani. (2005). Antropologi Kontemporer; Suatu Pengantar Kritis Mengenai Paradigma. Jakarta: Kencana Prenada Media Group.

Sendjaja, Sasa Djuarsa. (1999). Pengantar Komunikasi. Jakarta: Universitas Terbuka.

\section{Jurnal dan Laporan}

Haug, Michaela. (2007). Kemiskinan dan Desentralisasi di Kutai Barat: Dampak Otonomi Daerah Terhadap Kesejahteraan Dayak Benuaq. Cifor-BMZ.

Pattinama, J. Marcus. (2009). Pengentasan Kemiskinan Dengan Kearifan Lokal; Studi Kasus di Pulau Buru Maluku dan Surade Jawa Barat. Jurnal Makara Sosial Humaniora. Vol. 13 No. 1 Edisi Juli, hlm. 1-12.

Samiyono, David., Wayan Damayana., \& Sony Heru Priyanto. (2010). Dekontruksi Menyama Braya: Analisis Sosio Kultural Masyarakat Bali
Dalam Rangka Penyusunan Model Integrasi Bangsa dan Harmoni Sosial Bangsa Indonesia. Laporan Akhir Hibah Kompetitif Strategis Nasional dari Dikti. Salatiga: UKSW.

Sarmiati. (2012). Strategi Komunikasi Berbasis Kearifan Lokal Dalam Penanggulangan Kemiskinan. Jurnal Ilmu Komunikasi. Vol. 10 No. 1 Edisi Januari-April.

Sartini. (2004). Menggali Kearifan Lokal Nusantara, Sebuah Kajian Filsafat. Jurnal Filsafat. Jilid 37 No. 2 Edisi Agustus 2004, hlm. 119.

Suhartini. (2009). Kajian Kearifan Lokal Masyarakat Dalam Pengelolaan Sumber Daya Alam dan Lingkungan. Prosiding Seminar Nasional Penelitian dan Penerapan MIPA 16 Mei 2009. Yogyakarta: UNY.

\section{Sumber Internet}

http://www.indosiar.com/fokus/korban-smackdown-berjatuhan. (diakses pada 13 Januari 2013).

http://bambang-rustanto.blogspot. com/2012/04/komunitas-adat-dan pemberdayaan-sosial.html. (diakses 7 Agustus 2013).

Ira. 8 Desember 2012. (Online). (www.kpi.org, diakses 5 Mei 2013).

Khaerul, 28 September 2011. (Online). (www. Antaranews. com, diakses 13 Januari 2013). 